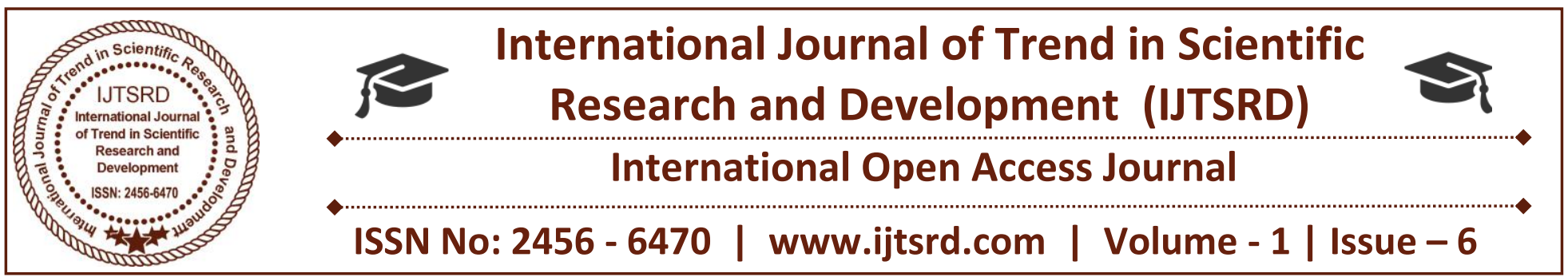

\title{
The Effect of Strategic Intelligence on Business Success in Selected Commercial Banks in South-East, Nigeria
}

\author{
Ndubuisi-Okolo Purity.U. \\ Department of Business Administration And Department of \\ Co-Operative Economy, Faculty of Management Sciences, \\ Nnamdi Azikiwe University, Awka, Anambra State, Nigeria
}

Anekwe Rita Ifeoma.

Department of Business Administration And Department of Co-Operative Economy, Faculty of Management Sciences, Nnamdi Azikiwe University, Awka, Anambra State, Nigeria

\section{ABSTRACT}

This study concentrated on the influence of strategic intelligence on business success. High rate of competition in today's banking industry constitutes a major challenge to growth and development. A survey research design was adopted. The justification for the adoption of survey research design is that the study made use of primary data which involves elicitation of responses via questionnaire from the respondents Data generated were analyzed utilizing Pearson Product Moment Correlation Coefficient. The result revealed that there is a significant positive relationship between strategic intelligence and business success. This depicts that effective strategic intelligence by firms leads to business success. In conclusion, Banks should also be flexible enough to adapt to the changes accruing from the external business environment.

Keywords: Strategic intelligence, competitive intelligence, business success and performance

\subsection{INTRODUCTION}

Competitive Intelligence is considered as a part of Decision Support Systems (Turban, Sharda and

\section{Theresa Anigbogu}

Ph.D, Department of Business Administration And Department of Co-Operative Economy, Faculty of Management Sciences, Nnamdi Azikiwe University, Awka, Anambra State, Nigeria

Delen,(2011).It has its origin in Management Information Systems of the 1970s. Executive

Information Systems then emerged in the 1980s and was automatically transformed into competitive intelligence. However, the development of CI was propelled by global competition; the emphasis on quality management and the realization by banks that actionable intelligence is a key towards competitive advantage. It also evolved from economics, marketing, military theory, information science and strategic management (Juhari and Stephens, 2006).

The adoption of CI within organizations has significantly contributed towards the sharing of ideas, addressing competitive dynamics, identifying new opportunities and avoiding threats. Competitive Intelligence is perceived as a panacea to the contemporary needs of organizations for strategic decision-making with intensive use of Modern Information Technology. Vitt, Luckevich and Misner (2002) state that competitive Intelligence covers myriad of technologies, software platforms, specific applications and processes. It is a multifaceted term that refers to processes, techniques or tools that 
enhance the making of faster and better decisions (Pirttimaki and Hannula, 2003).

In the word of Muller (2005), CI emerged in South Africa in the mid-1990s and early 2000s owing to its significance. South African enterprises have been too backward, which has made them vulnerable to unforeseen threats (Adidam, Gajre and Kejriwal, 2009). Chinese leaders have also considered intelligence as a useful means of helping to overcome its relative isolation from other economic and global trading systems (Chao, 1998; Tao and Prescott, 2000). Competitive intelligence in China is still relatively embryonic and patchy. Literature reveals that some countries including France, Japan, Sweden and the United State of America are more advanced in terms of the level in which organizations adopt and use CI. In these countries, competitive intelligence has earned its rightful place as an acknowledged business discipline and has become a major source to achieve competitive advantage.

Competitive intelligence is the systematic and continuous monitoring, collection, analysis and sharing of internal and external business information (Hirvensalo, 2004; Global Intelligence Alliance 2005; Knip and Fleisher, 2005). Also, the Strategic and Competitive Intelligence Professionals (SCIP) organization, as cited in Sharp (2009), defines CI as a necessary, ethical business discipline for decisionmaking based on understanding of the competitive environment. It is a management discipline that enables executives to make smarter, more successful decisions, thereby, minimizing risk, and avoiding surprises simultaneously.

Business organizations need strategic intelligence to improve and maintain their current status in a dynamic environment, especially in this critical period of economic recession and political quagmire. Strategic intelligence is a term used in the context of strategic planning and strategic management. It aims to understand where an organization is going, how it can retain its competitiveness in view of future challenges and changes in the long run (Thierauf, 2001) and how it can make the best strategic decisions for maximizing its success (Liebowitz, 2006). Strategic intelligence addresses the intelligence needs of high-level strategic decision makers, and the focus is primarily on proactive activities. It provides higher level intelligence on the competitive, economic and political environment in which your firms operate at present and in which it will operate in the future. Strategic intelligence is utilized by senior managers and executives who make and execute overall corporate strategy. Its most common applications are in the development of long term strategic plans, capital investment plans, political risk assessment, research and development planning. The strategic intelligence is a tool that helps the strategic management processes in organizations towards the planning and decision making, and it also improves the business performance through increasing knowledge and the internal and external communications (Gabber, 2007). It is evaluated with the factors such as the strategic vision, human and social resources, and the economical and political issues of the organizations (Gabber, 2007). The strategic intelligence relies heavily on the strategic planning system and strategic decision making of the organizations; it is seen as a concept which is widely related to the organization intelligence, organization strategies, strategic resources of organization, and strategic management (Richard, 2007). .

The banking sector is one of the fastest developing industries. Financial institutions produce millions of transactions daily stored in complex Information Systems. Efficient analysis of such large volumes of data is crucial for quick and real time decisionmaking. Contemporary corporate enterprises are always under stress to effectively and efficiently utilize information in order to solve complicated management problems. Turban et al (2011) and Petrini and Pozzebon (2003) are of the opinion that managing information in different enterprises is a major obstacle that demands decision-making processes focused on trusworthy, valuable and timely data. In view of this, (Argote and Ingarm 2000; Heinrich and Lim 2008; and Karim 2011) admit that knowledge translated into intelligence is the main source of competitive advantage. Based on the foregoing, this paper sets out to examine the influence of competitive intelligence on organizational performance as its main focus.

\subsection{Statement of the Problem}

Business environments are dynamic and for organizations to survive the dynamic nature of the environment, potential threats and opportunities in the external environment must be identified through strategic intelligence efforts. Strategic intelligence is a requirement for the survival of the Nigerian Banking 
Industry characterized by intense competition. Many organizations including the service industry are struggling to meet the tough and new competitive standards in speed, quality, efficiency and increased market share in order to become more competitive and flexible to meet customers' desired standard. This is because customers' needs, choices, preferences and awareness have also changed rapidly. But, the changes in the external environment of business have made some banks victims to their competitors, with some of them being forced to retrench their staff or reduce their number of branches as a way of coping with the intense competition. The invisibility of intelligence units in these banks is a major challenge confronting the banking industry.

But, without a proper intelligence structure in organizations, it is difficult to respond proactively to the changes in the competitive environment thereby creating room for faulty information to be generated which will mar effective and efficient decisionmaking process of the organization. This is because organizations rely more on information and knowledge since sustained growth and competitive authority are derived from knowledge.

\subsection{Objectives of the Study}

The broad objective of this study is to examine the nature of relationship between competitive intelligence and organizational performance in selected commercial banks in South-East, Nigeria..

The specific objective is:

I. To determine the nature of the relationship between strategic intelligence and business success in selected commercial banks in South East, Nigeria.

\section{Research Question}

i. What is the nature of the relationship between strategic intelligence and business success in selected commercial banks in South-East, Nigeria?

\section{Hypothesis}

Strategic intelligence has a significant relationship with business success in commercial banks in south east, Nigeria.

\subsection{Scope of the Study}

This study dwells on competitive intelligence and organizational performance in selected commercial banks in south-East, Nigeria. The work focused on strategic intelligence and business success.. The geographical scope of this work is South-East consisting of Enugu, Anambra, Imo, Ebonyi and Abia State. The justification for the choice of the geographical area is paucity of study on strategic intelligence and business success on banks in that area. The ten commercial banks selected for this research include Zenith Bank, Diamond Bank, Guarantee Trust Bank, First Bank Plc, Access Bank, First City Monument Bank, Fidelity Bank, United Bank for Africa, Stanbic Bank Plc and Sterling Bank.

\subsection{Conceptual Review}

Meaning of Strategic Intelligence

Strategic intelligence is a combination of different types of intelligence such as commercial intelligence and competitive intelligence as well as the issues of knowledge management for creation of the added value of information and knowledge for organizational strategic decision-making (Tarokh \& Hatami Lankarani 2010). This implies that for an organization to accomplish Its goals, combination of ideas, visions and foresight become very essential.

Strategic intelligence is a system that consists of several dimensions that are essential to create clearer image about the future; these dimensions can be summarized as per (Maccoby, 2011) by the following dimensions, (Foresight,Visioning Motivation). Strategic Intelligence is the gathering, analysis, and dissemination of data relevant to strategic decision making, (Fleisher and Bensoussan, 2007).

Strategic intelligence is a system that consists of several dimensions that are essential to create clearer image about the future; these dimensions can be summarized as per(Maccoby, 2011) by the following dimensions,

(Foresight, Visioning, Motivation)..Strategic intelligence is the specific form of analysis which is required for the formulation of policy and plans at agency, corporate, national or international levels.

\subsection{Theoretical Framework}

This research is anchored on Dynamic Capability Theory initially developed by David Teece and Gary Pisano (1994). The theory was introduced to explain firm performance in a dynamic environment, hinging on the capabilities that firms utilized to reach competitive advantage (Beske, Land, and Seuring, 2014). The theory stipulates that competitive advantage is attributed to those organizations that can react proactively to changes in the business 
environment while simultaneously possessing the capacity to manage firm specific capabilities in such a way as to effectively and efficiently coordinate and redeploy internal and external competencies (Teece et al, 1997). Dynamic capability is perceived as the ability to achieve competitive advantage by being strategic and flexible, dealing with the changes in the business environment through competitive intelligence efforts (Gizawi, 2014). Capabilities represent the key of strategic management in appropriately integrating, adapting and reconfiguring internal and external organizational resources, skills and competencies to match the requirements of a changing environment (Teece et al 1997). Since strategic intelligence aids decision-making by providing relevant, timely and reliable competitive knowledge and information, dynamic capability enables firms to react positively to the changes in the competitive arena. This theory has lent credence to the RBV propositions by advocating flexibility which leads to achieving competitive advantage in a dynamic environmental context.

\subsection{Empirical Review}

Mohmood Hemmatfar, Mahdi Salehi and Marziyeh Bayat (2010) sought to determine Competitive Advantages and Strategic Information Systems. The study stressed that knowledge management is a major factor in a competitive environment. This is because information system has a vital role in business operation and financial and non-financial aspect, such as decision-making. Cost leadership, differentiation and innovation are perceived as key indicators towards achieving a competitive advantage. It was found that strategic information system helps an organization to gain a competitive advantage through its contribution to the strategic goals of an organization and/or its ability to significantly increase performance and productivity.

Wadie Nasri and Mohamed Zarai (2013) identified Key Success Factors for Developing Competitive Intelligence in Organization. The purpose of this paper is twofold. First, to understand Competitive Intelligence (CI) and report the process that is commonly used to create and maintain a CI program in organizations. And second, to provide key success factors in developing a functional intelligence program for an organization. The investigators present a review of the literature on $\mathrm{CI}$ process to collect and analyze competitive information within organizations in order to identify key success factors in developing a functional intelligence program for an organization.
Five success factors can be defined as an item related to CI process: management support and understanding, focus and CI effort, location of CI function, CI personal, and product. The paper provides executive decision makers and strategic managers a better understanding of what $\mathrm{CI}$ process and appropriate to the decisions they must to develop a functional intelligence program for an organization.

Cartwright et al. (1995) surveyed seventy-four companies, which are members of the SCIP (Strategic and Competitive Intelligence Professionals). The study examined whether a relationship exists between perceived competitive intelligence usefulness in strategic decision making and strategic orientation of the firms and specific characteristics of competitive intelligence. The study found that technical adequacy (quality) and interaction with the competitive intelligence unit are the major characteristics influencing the perceived usefulness of competitive intelligence. Project-based competitive intelligence tends to be perceived useful regardless of strategic orientation of the firm. However, continuous competitive intelligence, both comprehensive and focus, was perceived differently by firms based on their strategic orientation. Prospectors and analyzers perceived these comprehensive types of competitive intelligence as more useful than did defenders and reactors.

Hasan Ali Al-Zu'bi (2016) examined aspects of strategic intelligence and its role in achieving organizational agility: An empirical investigation. The study aimed to identify the strategic intelligence dimensions (Visioning, Foresight, Partnership, Intuition, and Creativity) on achieving organizational agility in the Mining and Extraction Industries sector in Jordan. A study tool was developed (a questionnaire) for the purposes of collecting the primary data from the study population which consisted of (15) companies, with a total number of employees amounting to (8377) A total of (337) was chosen as a simple random representative sample of employees. The study revealed that all the strategic intelligence dimensions had an impact in achieving organizational agility, but the influence was more on dimensional creativity. The researcher recommended that Managers need to better understand how to evaluate, identify organizational agility in order achieve its set goals. 
Wadie Nasri (2012) sought to investigate the conceptual model of strategic benefits of competitive intelligence process. The purpose of this study is to explore theoretically how competitive intelligence process influence strategic benefits expansion in organization and also to explain the process that is commonly used to create and maintain a competitive intelligence system in organizations. A review of literature on competitive intelligence within organizations is reviewed to explore their current state, tools to collect, analyze, and communicate competitive information and the strategic benefits of the competitive intelligence process. The finding revealed that organizations tend to focus on developing competitive intelligence processes which provide the organization with sustainable competitive advantage. In conclusion, the rapidly changing business environment, the need for timely information is recognized as essential for organizations to succeed and survive in a competitive environment.

Carolina Schiefer (2013) researched on the role of competitive intelligence in strategic purchasing decisions and its influence on suppliers' resource allocation. The main thrust of the paper hooks on analyzing how competitor intelligence in strategic purchasing decisions affects the suppliers' resource allocation and leads to a competitive advantage. Based on an exploratory multiple-case study with ten Global Players, insights into strategic purchasing decisions and the consideration of competitor intelligence were gathered. Thus, this paper sets the first step towards theory building with respect to the use and effect of competitor intelligence in strategic purchasing. It was found that competitor intelligence is imperative for strategic purchasing decisions and positively affects the decision's outcome. Surprisingly, most of the companies perceive competitors sharing the same supplier to be a threat and an opportunity at the same time. Results indicated that while competitor intelligence may slightly affect the buyer-supplier relationship per se; the assumption that competitor information leads to a better resource allocation and ultimately positively affects a company's competitive advantage is widely accepted by the participants.

Mahmoud Reza Esmaeil (2014) investigated the effect of strategic intelligence on decision making and strategic planning. The present research aims to recognize not only the effective factors on the strategic intelligence, strategic decision making and strategic planning but also it studies the effect of the strategic intelligence on the strategic decision making and strategic planning in organization and companies using the intelligence system in the Khorram-abad city. An analytical-survey research was employed. The statistical population for the research is the companies and organizations using intelligent systems in Khorram-abad which were estimated using Cochran formula of the random samplingstratification method with a sample size of 150 . The research tool adopted was questionnaire which was confirmed through content validity method and its stability by Cronbach's Alpha. The structural equation approach and the AMOS 18 software were utilized to test the hypothesis. The result shows that the strategic intelligence has a positive and meaningful effect on the strategic decision making and strategic planning in the companies and organizations using the intelligent systems in Khorram-abad. In addition, the effective factors on the strategic intelligence, human resource intelligence, organizational process, technological, informational, financial resources, competitor, and customer intelligence were recognized.

Badr., Madden, \& Wright, (2006) examined Contribution of CI to the Strategic Decision Making Process: Empirical Study of the European Pharmaceutical Industry. The main aim of the study was to investigate the practices of competitive intelligence (CI) managers in the European pharmaceutical industry, specifically in relation to the contribution which CI made to the strategic decision making (SDM) process, regardless of firm size. CI managers in the European pharmaceutical industry were selected and the results from 79 copies of questionnaire and 14 in-depth interviews were provided. Results indicated that the CI activities in respondent firms are reasonably well established and also that the pharmaceutical industry appears to appreciate both the benefits, and requirements of a modern day CI function. Also, the industry is not taking full advantage of the CI effort at every stage of the SDM process.

Sabah Agha1, Eyad Atwa, Shadi Kiwan (2015) studied the impact of strategic intelligence on firm performance and the mediator role of strategic flexibility: An empirical research in biotechnology industry in Jordan, Amman. The main objective of this paper is to investigate the impact of strategic intelligence and its dimensions of (foresight, visioning, and motivation) on firm performance, and 
to examine the mediating role of strategic flexibility and its dimensions of (production flexibility, marketing flexibility and competitive flexibility) on such an impact in biotechnology industry firms. The statistical package for social sciences (SPSS) program and AMOS software were used to analyze and examine the hypotheses. After executing the analysis to test hypotheses; the research concluded that there are significant positive impacts of strategic intelligence on firm performance, positive impacts of strategic intelligence, on strategic flexibility, and positive impacts of strategic intelligence on firm performance in the presence of strategic flexibility as a mediator variable.

\subsection{Research Design}

This study employed survey research design. The justification for the adoption of Survey is that it anchors on description of a phenomenon and involves questioning individuals on topics and then describing their responses (Jackson, 2011).It involves gathering of opinions and information from respondents which addresses the research objectives and research questions. The dominant methods of the survey designs are the administration of copies of questionnaire and interviews.

\subsection{Sources of Data}

Data for this study were generated from both primary and secondary sources.

3.2.1 Primary Sources of Data: Are perceived as first-hand information generated to solve specific problems. They are data collected specifically for a purpose. They are usually collected from the field under the control and supervision of an investigator. Primary sources include interview, questionnaire and observations.

3.2.2 Secondary Sources of Data: Are existing data that have been collected by other researchers for other purposes but which are essential to the current research. Secondary data also refers to data that is used for a purpose other than for which it was originally generated. It may be descriptive or explanatory (Saunders, Lewis, \& Thornhill 2007), raw (unprocessed) or summarized. Secondary data for the research was collected by reviewing textbooks, journals, articles, magazines, publication and relevant documented materials from the organizations of study.

\subsection{Population of the Study}

The target population of the study comprises both junior and senior staff of the ten selected banks in South- East Region of Nigeria. The population status is 16,265. These banks include Zenith Bank, Diamond Bank, Guarantee Trust Bank, First Bank plc, Access Bank, Fidelity Bank, First City Monument Bank, United Bank for Africa, Stanbic Bank Plc, and Sterling Bank. The first three were rated top Nigerian Banks by Customer Satisfaction Index Rating in terms of customer care, convenience and transaction methods/systems (KPMG, 2014) while the remaining seven banks were selected based on their competitive nature in the banking industry in Nigeria. The statistical information concerning the selected banks is given below:

Table 3.1 Breakdown of the Population Distribution

\begin{tabular}{|c|c|c|c|c|}
\hline $\mathrm{S} / \mathbf{N}$ & Selected Banks & $\begin{array}{l}\text { Junior } \\
\text { Staff }\end{array}$ & $\begin{array}{l}\text { Senior } \\
\text { Staff }\end{array}$ & Total \\
\hline 1 & Zenith Bank & 720 & 850 & 1570 \\
\hline 2 & Diamond Bank & 525 & 920 & 1445 \\
\hline 3 & Guarantee Trust Bank & 580 & 740 & 1320 \\
\hline 4 & First Bank Ng Plc & 840 & 1000 & 1840 \\
\hline 5 & Access Bank & 525 & 745 & 1270 \\
\hline 6 & Fidelity Bank & 600 & 750 & 1350 \\
\hline 7 & $\begin{array}{l}\text { First City Monument } \\
\text { Bank }\end{array}$ & 960 & 1050 & 2010 \\
\hline 8 & $\begin{array}{l}\text { United Bank for } \\
\text { Africa }\end{array}$ & 930 & 1050 & 1980 \\
\hline
\end{tabular}


International Journal of Trend in Scientific Research and Development (IJTSRD) ISSN: 2456-6470

\begin{tabular}{|l|l|l|l|l|}
\hline 9 & $\begin{array}{l}\text { Stanbic IBCT Bank } \\
\text { PLC }\end{array}$ & 740 & 970 & 1710 \\
\hline 10 & Sterling Bank & 850 & 920 & 1770 \\
\hline Total & 7270 & 8995 & 16,265 \\
\hline
\end{tabular}

Source: Human Resource Department (2015).

\subsection{Pilot Survey}

A pilot survey was conducted in which one hundred (100) copies of the questionnaire were randomly distributed to some staff of the selected banks in South-East Nigeria. The pilot survey was used to determine the sample size. Ninety(90) out of the hundred(100) respondents returned representing 0.90 positive rating while only ten(10) defaulted representing $(0.10)$ negative response.

\subsection{Sample Size Determination and Sampling Technique}

Sampling represents the process of selecting a subset of observations from among many possible observations. It ensures that all the elements of the population under study are fully represented. The accuracy of statistical inference relies heavily on the accuracy of sample and sampling technique. The Stratified Random Sampling was adopted in this study. The method was used because of the nature of the population. This research certified Cooper and Schinder (2006) criteria for adopting stratified random sampling technique which include: increased sample's statistical efficiency and adequacy of data for analyzing the various sub-population or strata. In addition, it was also utilized in this study to ensure that banks with different numerical strengths are well represented. The Freund and Williams's formula as cited by Agbadudu (2004) was adopted to determine the sample size for the study. The formula is given below:

$$
\frac{\mathrm{n}=\mathrm{Z}^{2} p q}{\mathrm{e}^{2}}
$$

Where:

$$
\mathrm{n}=\text { sample size }
$$

$\mathrm{p}=$ percentage of positive response

$\mathrm{q}=$ percentage of negative response

$\mathrm{e}=$ margin of error

$\mathrm{Z}=$ level of confidence

To generate the $\mathrm{p}$ and $\mathrm{q}$ values for the simple size formula, the result of our pilot study was employed.

$90=0.90 . p=0.90$
$10=0.10 . \quad q=0.10$

At $\mathrm{e}=0.05$ (margin of error), $Z=1.96$. Thus, we have $\underline{\eta}=(1.960)^{2}(0.90)(0.10)$

$(0.025)^{2}$

$$
\begin{aligned}
& \eta=553 \\
& \eta=553
\end{aligned}
$$

Table 3.2 below shows the proportional stratification and allocation of the sample 553 to senior and junior staff of the selected banks.

\begin{tabular}{|c|l|l|l|c|}
\hline S/N & $\begin{array}{l}\text { Selected } \\
\text { Banks }\end{array}$ & $\begin{array}{l}\text { Junior } \\
\text { Staff }\end{array}$ & $\begin{array}{l}\text { Sample } \\
\text { Staff } \\
\text { size }\end{array}$ \\
\hline 1 & $\begin{array}{l}\text { Zenith Bank } \\
\text { NigPlc }\end{array}$ & $553 \times 720 / 16,265=24$ & $553 \times 850 / 16,265=29$ & 53 \\
\hline 2 & $\begin{array}{l}\text { Diamond Bank plc } \\
553 \times 525 / 16,265=24\end{array}$ & $553 \times 920 / 16,265=31$ & 55 \\
\hline 3 & $\begin{array}{l}\text { Guarantee Trust } \\
\text { Bank }\end{array}$ & $553 \times 580 / 16,265=20$ & $553 \times 740 / 16,265=25$ & 45 \\
\hline 4 & First Bank plc & $553 \times 840 / 16265=29$ & $553 \times 1000 / 16,265=34$ & 63 \\
\hline
\end{tabular}


International Journal of Trend in Scientific Research and Development (IJTSRD) ISSN: 2456-6470

\begin{tabular}{|c|l|l|l|c|}
\hline 5 & Access Bank & $553 \times 525 / 16265=18$ & $553 \times 745 / 16,265=25$ & 43 \\
\hline 6 & Fidelity City & $553 \times 600 / 16,265=22$ & $553 \times 750 / 16,265=25$ & 47 \\
\hline 7 & $\begin{array}{l}\text { First } \\
\text { Monument Bank }\end{array}$ & $553 \times 1050 / 16265=37$ & 71 \\
\hline 8 & $\begin{array}{l}\text { United Bank for } \\
\text { Africa }\end{array}$ & $553 \times 760 / 16265=25$ & $553 \times 890 / 16265=30$ & 55 \\
\hline 9 & $\begin{array}{l}\text { Stanbic Bank } \\
\text { IBCT }\end{array}$ & $553 \times 740 / 16265=26$ & $553 \times 970 / 16265=33$ & 59 \\
\hline 10 & $\begin{array}{l}\text { Sterling Bank } \\
\text { Total }\end{array}$ & $553 \times 850 / 16265=29$ & 60 \\
\hline
\end{tabular}

Source: Human Resource Department, 2015

A total number of 553 respondents were used for this study as the sample size. After the sample size was calculated, the values were allocated proportionately to the ten (10) deposit money banks hinging on the proportion of the population of each bank. .

\subsection{Description of the Research Instrument}

Research instrument refers to the various tools for primary data collection. Saunders, Lewis and Thornhill (2007) list questionnaire, interviews (semistructured, in-depth and group) and observation as methods that are applicable. But, for the purpose of this study, the key instruments that were adopted are structured questionnaire and oral interview aimed at eliciting detailed and factual information. The questionnaire method is very essential because it provides an efficient way of gathering responses from a large population. In the words of Ezejelue, Ogwo and Nkamnebe, (2008), it is the most popular method of data collection. The questionnaire was structured to place the respondents on objective response for each statement on five-point Likert scale. The response scoring rates are: 5 for strongly agree (SA), 4 for Agree (A), 3 for undecided (U), 2 for Disagree (D), and 1 for strongly Disagree (SD). The questionnaire which was tagged' Competitive Intelligence and Organizational Performance were categorized into three sections. Section A carried a covering letter, section B focused on questions on the respondents' demographic characteristics (bio-data), and section $\mathrm{C}$ contained questions on competitive intelligence proxies and organizational performance indices. The administration of the questionnaire cut across the ten banks chosen for this study. The competitive intelligence construct was measured on six dimensions (competitor, strategic, technology, customer, market and product) and the organizational performance construct was decomposed into six (market share, business success, innovation, quality service delivery, productivity and customer satisfaction).

Oral interview was conducted to generate more information from the respondents of the banks. The interview helped the researcher to gather some relevant facts and information that could not be gathered through questionnaire.

\subsection{Validity of the Instrument}

To test the validity of the instrument, construct and content validity were conducted by the researcher. The validity of the instrument for measurement according to Asika (2006) refers to the extent or degree to which the instrument measures what it is purported to measure. To ensure that the instrument for this study effectively measure what it was designed for, the items of the questionnaire were given to panel of experts in the discipline and organizations of study for thorough scrutinizing with the intention of ensuring that all relevant variables of the study are captured in the copies of questionnaire. The variables are the objectives, research questions and the hypotheses of the study which were properly well-structured in conjunction with the reviewed literature. The purpose is to ensure that the content validity of the research instrument is assured.

\subsection{Reliability of the Study}

Reliability refers to the consistency of the measuring instrument overtime. Pallant (2008) states that a Cronbach alpha of 0.70 or above is generally recommended or considered appropriate for studies in 
Social Science Research. Responses on a summated scale showed consistency across questions, which indicated that the questions are measuring the same thing (internal consistency) (Spector, 1992).Cronbach Alpha was used to measure the internal consistency. A reliability coefficient demonstrates whether the test designer was correct in expecting a certain collection of items to yield interpretable statements about individual differences (Kelley, 1942). The reliability coefficient for the scales are: strategic intelligence (.711); business success (821) ; All scales showed values which are greater than .70 , a threshold considered suitable for most studies (Hair, Black, Babin, Anderson, \& Tatham, 2006).

\subsection{Method of Data Analyses}

To analyze the data for this research work, both descriptive and inferential statistical tools were adopted to lend credence to this work. The descriptive statistical tools that were employed include mean, percentages and standard deviation. The inferential statistical tools utilized are Pearson Product Moment Correlation using SPSS Version 20 and Simple Regression Analysis. Correlation Analysis showcases the interdependence of the study variables. Statistical correlation is significant if coefficient is more than 0.5 . Moreover, if P-value is low (under 0.01), it implies that the correlation actually exists.

3. 10 Decision Rule: In order to test the one formulated hypothesis, the study employed the Pearson Product Moment Correlation Coefficient [PPMCC] computed with the aid of Statistical Package for Social Sciences (SPSS) Version 20 and Simple Linear Regression Analysis.

The decision rule is stated as follows:

If $P<.01$, we reject the null and accept the alternate; or,

If $P>.01$, we reject the alternate and accept the null.

Table 4.1 Distribution and Return of the Questionnaire

\begin{tabular}{|l|l|l|l|l|l|l|}
\hline Firms & $\begin{array}{l}\text { No } \\
\text { Distributed }\end{array}$ & $\%$ & $\begin{array}{l}\text { No } \\
\text { Returned }\end{array}$ & $\%$ & $\begin{array}{l}\text { No not } \\
\text { Returned }\end{array}$ & $\%$ \\
\hline Zenith Bank Nig Plc & 53 & 9.6 & 46 & 8. & 7 & 1.3 \\
\hline Diamond Bank Plc & 55 & 9.9 & 50 & 9 & 5 & 0.9 \\
\hline Guarantee Trust Bank Plc & 45 & 8.1 & 42 & 8 & 3 & 0.5 \\
\hline First Bank Plc & 63 & 11.4 & 56 & 10 & 7 & 1.3 \\
\hline Access Bank Plc & 43 & 7.8 & 40 & 7 & 3 & 0.5 \\
\hline Fidelity Bank plc & 47 & 8.5 & 43 & 8 & 4 & 0.7 \\
\hline First City Monument Bank & 71 & 12.8 & 64 & 12 & 7 & 1.3 \\
\hline United Bank for Africa Plc & 55 & 9.9 & 50 & 9 & 5 & 0.9 \\
\hline Stanbic Bank IBCT Plc & 59 & 10.7 & 54 & 10 & 5 & 0.9 \\
\hline Sterling Bank Plc & 60 & 10.8 & 57 & 10 & 3 & 0.5 \\
\hline Total & $\mathbf{5 5 3}$ & $\mathbf{1 0 0}$ & $\mathbf{5 0 2}$ & $\mathbf{9 1}$ & $\mathbf{5 1}$ & $\mathbf{9}$ \\
\hline
\end{tabular}

\section{Source: Field Survey 2016}

Table 4.1 shows that 502 (91\%) of the copies of the questionnaire distributed were returned while 51 (9\%) were not returned and was not used.

\subsection{To determine the nature of the relationship between strategic intelligence and business success in} commercial banks in South-East, Nigeria.

\begin{tabular}{|l|l|l|l|l|l|l|l|}
\hline S/No & Statement & SA & $\mathbf{A}$ & $\mathbf{N}$ & $\mathbf{D}$ & SD & Total \\
& & $\%$ & $\%$ & $\%$ & $\%$ & $\%$ & \\
\hline 7 & There is a significant relationship between strategic & 386 & 89 & 14 & 11 & 2 & 502 \\
\hline
\end{tabular}


International Journal of Trend in Scientific Research and Development (IJTSRD) ISSN: 2456-6470

\begin{tabular}{|c|c|c|c|c|c|c|c|}
\hline & intelligence and business success & $76.9 \%$ & $17.7 \%$ & $2.8 \%$ & $2.2 \%$ & $0.4 \%$ & \\
\hline 8 & $\begin{array}{l}\text { There is a negative relationship between strategic } \\
\text { intelligence and business success }\end{array}$ & $\begin{array}{l}40 \\
7.10 \%\end{array}$ & $\begin{array}{l}78 \\
15.5 \%\end{array}$ & $\begin{array}{l}58 \\
11.6 \%\end{array}$ & $\begin{array}{l}178 \\
35.5 \%\end{array}$ & $\begin{array}{l}148 \\
29.5 \%\end{array}$ & 502 \\
\hline 9 & $\begin{array}{l}\text { Our ability to think strategically has really enhanced } \\
\text { the competitive status of our bank }\end{array}$ & $\begin{array}{l}460 \\
91.6 \%\end{array}$ & $\begin{array}{l}37 \\
7.4 \%\end{array}$ & $\begin{array}{l}1 \\
0.2 \%\end{array}$ & $\begin{array}{l}2 \\
0.4 \%\end{array}$ & $\begin{array}{l}2 \\
0.4 \%\end{array}$ & 502 \\
\hline 10 & $\begin{array}{l}\text { The relationship between strategic intelligence and } \\
\text { business success is not obvious }\end{array}$ & $\begin{array}{l}211 \\
42.0 \%\end{array}$ & $\begin{array}{l}107 \\
21.3 \%\end{array}$ & $\begin{array}{l}45 \\
9.0 \%\end{array}$ & $\begin{array}{l}129 \\
25.7 \%\end{array}$ & $\begin{array}{l}10 \\
1.10 \%\end{array}$ & 502 \\
\hline 11 & $\begin{array}{l}\text { We survive through meeting the needs, wants and } \\
\text { providing benefits for customers }\end{array}$ & $\begin{array}{l}389 \\
77.5 \%\end{array}$ & $\begin{array}{l}98 \\
19.5 \%\end{array}$ & $\begin{array}{l}5 \\
1.0 \%\end{array}$ & $\begin{array}{l}4 \\
0.8 \%\end{array}$ & $\begin{array}{l}6 \\
1.2 \%\end{array}$ & 502 \\
\hline 12 & $\begin{array}{l}\text { There is no relationship between strategic } \\
\text { intelligence and business success }\end{array}$ & $\begin{array}{l}83 \\
16.5 \%\end{array}$ & $\begin{array}{l}86 \\
17.1 \%\end{array}$ & $\begin{array}{l}40 \\
7.10 \%\end{array}$ & $\begin{array}{l}197 \\
39.2 \%\end{array}$ & $\begin{array}{l}96 \\
19.1 \%\end{array}$ & 502 \\
\hline
\end{tabular}

\section{Source: Field Survey (2016)}

Item 7 of table 4.2 Indicates that $386(76.9 \%)$ of the respondents strongly agreed with the Statement that there is a significant relationship between strategic intelligence and business success. 89(17.7\%) agreed, $14(2.8 \%)$ were undecided, 11(2.2\%) disagreed while $2(0.4 \%)$ strongly disagreed that there is a significant relationship between strategic intelligence and business success.

Item 8 of the table 4.2 states that there is a negative relationship between strategic intelligence and business success. 40(7.10\%) strongly agreed with the statement, $89(17.7 \%)$ agreed, 58(11.6\%) were undecided, 178(35.5\%) disagreed while 148 (29.5\%) strongly disagreed that there is a negative relationship between strategic intelligence and business success.

In item 9 of the table $4.3,460(91.6 \%)$ of the respondents strongly agreed that our ability to think strategically has really enhanced the competitive status of our bank, 37(7.4\%) agreed, 1(0.2\%) were undecided, $2(0.4 \%)$ disagreed while $2(0.2 \%)$ strongly disagreed that our ability to think strategically has really enhanced the competitive status of our bank.

In item 10 of the table 4.2, 211(42.0\%) of the respondents strongly agreed that the relationship between strategic intelligence and business success is not obvious, $107(21.3 \%)$ agreed, 45(9.0\%) were undecided, 129(25.7\%) disagreed while 10(1.10\%) strongly disagreed that the relationship between strategic intelligence and business success is not obvious.

In item 11 of the table 4.2, 389(77.5\%) of the respondents strongly agreed that we survive through meeting the needs, wants and providing benefits for customers, 98 (19.5\%) agreed, 5(1.0\%) were undecided, $4(0.8 \%)$ disagreed while $6(1.2 \%)$ strongly disagreed that we survive through meeting the needs, wants and providing benefits for customers.
In item 12 of the table 4.2, 83(16.5\%) of the respondents strongly agreed that there is no relationship between strategic intelligence and business success, $86(17.1 \%)$ agreed, 40(7.10\%) were undecided, 197(39.2\%) disagreed while 96(19.16\%) strongly disagreed that there is no relationship between strategic intelligence and business success.

\section{Test of Hypothesis}

Ho: Strategic intelligence has no significant relationship with business success in deposit money banks in South East Nigeria

$\mathrm{H}_{1}$ : Strategic intelligence has a significant relationship with business success in deposit money banks in South East Nigeria

\begin{tabular}{|l|l|l|l|}
\hline \multicolumn{4}{|c|}{ Table 4.11 Descriptive Statistics } \\
\hline & Mean & $\begin{array}{l}\text { Std. } \\
\text { Deviation }\end{array}$ & N \\
\hline $\begin{array}{l}\text { strategic } \\
\text { intelligence }\end{array}$ & 1.4183 & .72886 & 502 \\
\hline business success & 1.6195 & .67509 & 502 \\
\hline
\end{tabular}

Source: SPSS Version, 20.00

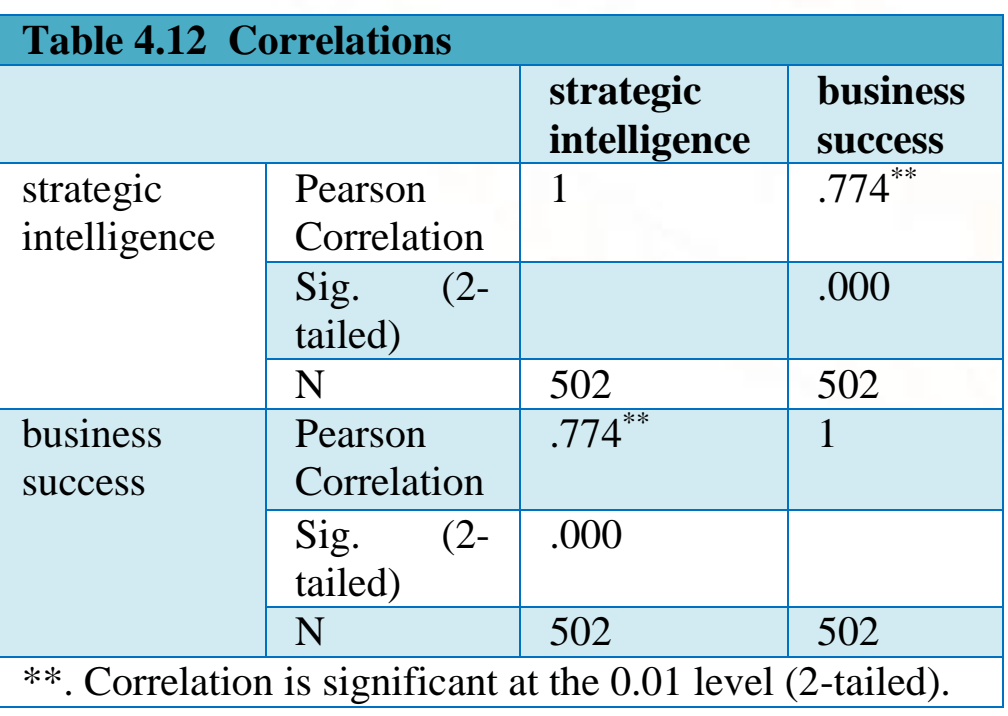


Source: SPSS Version, 20.00

Table (4.12) shows the descriptive statistics of the strategic intelligence and business success with a mean response of 1.4183 and std. deviation of .72886 for strategic intelligence and a mean response of 1.6195 and std. deviation of .67509 for business success and number of respondents (502). By careful observation of standard deviation values, there is not much difference in terms of the standard deviation scores. This implies that there is about the same variability of data points between the dependent and independent variables.

Table (4.12) is the Pearson correlation coefficient for strategic intelligence and business success. The correlation coefficient shows 0.774 . This value indicates that correlation is significant at 0.05 level (2tailed) and implies that there is a significant positive relationship between strategic intelligence and business success $(\mathrm{r}=.774)$. The computed correlations coefficient is greater than the table value of $\mathrm{r}=.195$ with 500 degrees of freedom $\quad(\mathrm{df} .=\mathrm{n}-2)$ at alpha level for a two-tailed test $(r=.774, p<.05)$. However, since the computed $r=.774$, is greater than the table value of .195 we reject the null hypothesis and concluded that strategic intelligence has a significant positive relationship on business success ( $\mathrm{r}$ $=.774, \mathrm{P}<.05)$.

\section{Result and Discussion of finding}

The researcher found out that 'Strategic intelligence has a significant positive relationship with business success in deposit money banks in South-East, Nigeria. This finding is in tandem with a similar study conducted by Mohmood Hemmatfar,Mahdi Salehi and Marziyeh Bayat (2010) which state that strategic information system helps an organization to gain a competitive advantage through its contribution to the strategic goals of an organization and/or its ability to significantly increase performance. Strategic intelligence aims to understand where an organization is going, how it can retain its competitiveness in view of future challenges and changes in the long run (Thierauf, 2001) and how it can make the best strategic decisions for maximizing its success (Liebowitz, 2006). Based on the interview conducted, practically all respondents supported the idea that strategic intelligence has link with business success. This is because strategic intelligence addresses the intelligence needs of high-level strategic decision makers, and the focus is mainly on proactive activities that pave way for organizational success. It provides higher level intelligence on the competitive, economic and political environment in which your firms operate at present and in which it will operate in the future. The ability of a firm to master information and knowledge constitutes an essential factor in business success (Lapointe,1995; Porter, 1990).Business success is measured in terms of market share, profits and return on investment. Information and the ability to exploit intelligence information are the means by which business are able to identify new opportunities and acquire new knowledge. This helps them quickly get on the same page with regard to competitive understanding and move more quickly toward devising strategies and plans to maximize competitive advantage (Wright \& Calof, 2006). Strategic Intelligence helps organizations to forecast future trends which pave way for organizations competitiveness in a turbulent and dynamic environment in which we find ourselves today. This study is also in line with views expressed by Sabah Agha1, Eyad Atwa, Shadi Kiwan (2015) that there are significant positive impacts of strategic intelligence on firm performance, positive impacts of strategic intelligence, on strategic flexibility, and positive impacts of strategic intelligence on firm performance in the presence of strategic flexibility as a mediator variable. In another similar study conducted by Rashad Al Saed (2013), the result indicates that there is a positive relationship between the business intelligence and business success. This depicts that the success of any business relies heavily on its ability to make forecast,that is, being able to predict present and future trends.

\section{Conclusion and Recommendation}

The result of the analysis conducted revealed that Strategic intelligence has a significant positive relationship with business success. This implies that survival of banks depends on its proactive and reactive nature in sync with the happenings in the competitive environment. Banks should also be flexible enough to adapt to the changes accruing from the external business environment.

\section{REFERENCES}

1) Adidam, T.J., Gajre, S. and Kejriwal, S. (2009). Cross-cultural competitive intelligence strategies. Marketing Intelligence \& Planning, 27(5), 666-680.

2) Tarokh, Mohammad Jafar \& Hatami Lankarani, Ferdous (2010). Strategic Intelligence and 
Knowledge Management: How Organizations can Improve their Decision-making Process Published by University of Khaje Nasir.

3) Maccoby, M., (2011).Strategic Intelligence: conceptual system of leadership for change. Performance Improvement, 31-40.

4) Fleisher, C. \& Bensoussan, B. 2007. Business and Competitive Analysis: effective application. Upper Saddle River: FT Press.

5) Badr, A., Madden, E. \& Wright, S., (2006). The contribution of $\mathrm{CI}$ to the strategic decision making process: Empirical study of the European pharmaceutical industry', Journal of Competitive Intelligence and Management 3(4), 15-35.

6) Carolina Schiefer (2013). The Role of Competitive intelligence in strategic purchasing decisions and its influence on suppliers' resource allocation. Unpublished Master Thesis, Technical University of Berlin

7) .Cartwright, D. L., Boughton, P. D.and Miller, S. W. (1995). Competitive intelligence systems: relationships to strategic orientation and perceived usefulness. Journal of Managerial Issues, 7(4), 420-434.

8) Cooper, R. (2000). Information technology development creativity; a case study of attempted radical change, MIS QUARTERLY, 24(2), 245-276.

9) Ezejolue, A.O, Ogwo, E.O and Nkamnebe, A. D (2008). Basic Principles in Managing Research Project, Aba: Afrilowers Limited.

10) Gabber. H., (2007).Competitive intelligence topology analyze for improved plan operation.
Industrial Management and Data Systems, 107(2): 198-236.

11) KPMG (2014). Banking Industry Customer Satisfaction Survey.

12) Nasri, W. and Charfeddine, L.,(2012). Motivating salespeople to contribute to marketing intelligence activities: An expectancy theory approach', International Journal of Marketing Studies 4(1), 168-175. http://dx.doi.org/10.5539/ijms.4 (1), 168.

13) Petrini, M. and M. Pozzebon,(2003). The value of "business intelligence" in the context of developing countries. Proceedings of 11th European Conference on Information Systems in Italy.

14) Pirttimaki, V. and Hannula, M. (2003). Process Models of Business Intelligence. Proceedings of the Frontiers of E-Business Research Conference. City offset Oy, Tampere, Finland,: 250-260.

15) Saunders, M., Lewis, P. and Thornhill, A. (2007) Research Methods for Business Students 4th ed. Prentice Hall..

16) Spector, P. A. (1992). Summated Rating Scale Construction: An Introduction. Newbury Park, CA, Sage.

17) Vitt, E., M; Luckevich and Misner, S.(2002). Business Intelligence: Making Better Decisions Faster. Microsoft Press, Redmond, Washington.

18) Wadie Nasri1 and Mohamed Zarai (2013) identified Key Success Factors for Developing Competitive Intelligence in Organization. American Journal of Business and Management 2(3), 239-244. 